\title{
The Overexpression of Kinesin Superfamily Protein 2A (KIF2A) Was Associated with the Proliferation and Prognosis of Esophageal Squamous Cell Carcinoma [Retraction]
}

\author{
Li D, Sun H, Meng L, Li D. Cancer Manag Res. 2020;12:3731-3739
}

The Editor and Publisher of Cancer Management and Research wish to retract the published article. Concerns were raised following a request from the authors to replace in vivo and immunohistochemistry (IHC) images in Figure 4 due to the authors having lost the original data and being unable to verify the findings as reported. The authors could not provide a satisfactory explanation for how their repeated experiments supported the original findings, given the original data was no longer available. In addition, the animal ethics approval documents provided by the authors for the original study were not satisfactory. The findings of the article were deemed unreliable, and the Editor requested for the article to be retracted.

Our decision-making was informed by our policy on publishing ethics and integrity and the COPE guidelines on retraction.

The retracted article will remain online to maintain the scholarly record, but it will be digitally watermarked on each page as "Retracted".

\section{Publish your work in this journal}

Cancer Management and Research is an international, peer-reviewed open access journal focusing on cancer research and the optimal use of preventative and integrated treatment interventions to achieve improved outcomes, enhanced survival and quality of life for the cancer patient. The manuscript management system is completely online and includes a very quick and fair peer-review system, which is all easy to use. Visit http://www.dovepress.com/testimonials.php to read real quotes from published authors. 